УДК 636.4.082.43 DOI 10.31210/visnyk2018.03.16

(C) 2018

Повод М. Г., доктор сільськогосподарських наук, професор,

Шиетний М. Б., старший викладач

Сумський національний аграрний університет

\title{
СЕЗОННА ДИНАМІКА ПРОДУКТИВНОСТІ ПОРОСЯТ ЗА ДОРОЩУВАННЯ ЇХ У СТАНКАХ ІЗ РІЗНИМ ТИПОМ ПІДЛОГИ
}

\section{Рецензент - доктор сільськогосподарських наук С. Л. Войтенко}

\begin{abstract}
Вивчалась сезонна динаміка продуктивності поросят за дорошування їх у станках з полімерною та бетонною перфорованими підлогами. Встановлено залежність продуктивності поросят на дорощуванні від типу перфорованої підлоги в станку впродовж усіх пір року. Поросята, які дорощувались із заміною в станку полімерної перфорованої підлоги на бетонну, щзооби споживали в розрахунку на одну голову на 7,7-13,8\% менше корму, мали на 5,7-18,4\% нижчі середньодобові, на 7,8-18,5\% - абсолютні та на 4,810,2\% - відносні прирости, в результаті чого по його закінченню мали меншу на 7,8-13,1\% живу масу. У них також на 3,2-5,0\% була гіршою конверсія корму, та на 3,0-5,9\% - збереженість поросят, ніж y їх аналогів, які утримувались у станках із полімерною перфорованою підлогою.
\end{abstract}

Ключові слова: поросята, тип підлоги, середньодобові прирости, споживання корму, конверсія корму, збереженість

Постановка проблеми. В Україні, як і в більшості країн Європи, свинарство є галуззю тваринництва, яка динамічно розвивається. Більшість виробників свинини, незалежно від розмірів ферми, впроваджують індустріальні технології іiі виробництва, за яких основні технологічні групи утримуються з використанням перфорованої підлоги. Дискусійним на сьогоднішній день $\epsilon$ питання частки перфорованої підлоги в станку, матеріалів, з яких виготовляється ця підлога, розмірів граток та інше. Тому вельми актуальним $€$ порівняльне вивчення динаміки продуктивності свиней залежно від конструктивних особливостей підлоги в станку.

Аналіз останніх досліджень і публікацій, у яких започатковано розв'язання проблеми. Продуктивність свиней визначається не тільки рівнем і повноцінністю годівлі, породними особливостями тварин, а й, значною мірою, умовами їхнього утримання $[1,2,5,7]$. Але утримання тварин на промислових комплексах в умовах постійного впливу технологічних стресів призводить до зниження резистентності тварин i, як наслідок, погіршення їхньої продуктивності. Особливо це стосується такої вразливої техноло- гічної групи як поросята-відлученці $[1,2,6,8]$. За свідченням багатьох авторів [1, 2, 7-9], створення оптимальних умов утримання у період дорощування поросят сприяє кращій їх адаптації до нових умов, покращує збереженість, підвищує енергію росту та оплату корму приростами, створює кращі стартові умови на початковому етапі відгодівлі. Проте індустріалізація утримання тварин не завжди відповідає їх фізіологічним та етологічним потребам і створює дискомфорт для життєздатності $[1,2,7]$.

Тому, як свідчать наступні автори [2-5, 8, 9], виробники свинини продовжують пошук систем утримання свиней, які б оптимально поєднували фізіологічні потреби тварини та були економічно доцільними.

У зв'язку з цим, метою нашої роботи стало проведення порівняння інтенсивності росту, витрат корму, стану здоров'я і збереженості молодняку свиней на дорощуванні за різного типу підлоги впродовж усіх сезонів року.

Матеріали і методи досліджень. Матеріалом досліджень були продуктивні якості поросятвідлученців, яких утримували у станках із різними конструктивними особливостями підлог упродовж різних пір року. Для порівняння інтенсивності росту, витрат корму, стану здоров'я i збереженості молодняку свиней під час його дорощування за різного типу підлоги було проведено науково-господарський дослід, задля якого впродовж кожної пори року було сформовано, за методом груп аналогів, по дві групи поросятвідлученців віком 28 діб в кількості по 160 голів кожна, які були поставлені на дорощування в приміщення за однотипної системи підтримання мікроклімату, в станках однакової конструкції на частково щілинній підлозі з розрахунку $0,32 \mathrm{~m}^{2}$ на голову. Утримання поросят контрольної групи відбувалось у станках на частково перфорованій полімерній підлозі, а їх аналогів дослідної групи здійснювалось у станках на частково перфорованій бетонній підлозі з розміром щілин 15 мм.

Умови утримання поросят усіх груп були ідентичними упродовж досліду. 


\section{СІЛЬСЬКЕ ГОСПОДАРСТВО. ТВАРИННИЦТВО}

Вентиляція в обох приміщеннях була негативного тиску і підтримувалась автоматично. Обігрів здійснювався за допомогою водяного опалення, вмонтованого в суцільну частину підлоги. Місце відпочинку для поросят становило 3 розрахунку $0,15 \mathrm{м}^{2}$ на голову.

Годівля поросят обох груп здійснювалась сухими, розсипчастими, повнораціонними комбікормами без обмеження 3 кормових автоматів $\mathrm{i}$ була аналогічною, повноцінною та збалансованою. Облік корму проводився упродовж усього періоду дорощування шляхом завантаження комбікорму вручну при закритих шиберах лінії кормороздачі. Напування поросят піддослідних груп проводилось за допомогою соскових автонапувалок.

Видалення гною з-під решітчастої підлоги станків у приміщеннях здійснювалось за допомогою вакуумно-самопливної системи періодичної дії. Терміни початку та закінчення дорощування були підібрані так, що вони припадали виключно на пору року, яка досліджувалась.

За результатами досліду вивчались: збереженість поросят, прирости їх живої маси за період дорощування. По закінченню дослідження було вирахувано середню кількість витраченого комбікорму на одне порося на добу і на 1 кг приросту.

Результати досліду оброблені біометрично, за загально прийнятими методиками 3 допомогою персонального комп'ютера та пакету прикладних програм.

Результати дослідження свідчать, що при вивченні залежності господарськи корисних ознак за дорощування їх в станках із різним типом підлоги в жорстких умовах зимової пори року встановлено, що тварини, які утримувались у станках з полімерною підлогою, щодоби споживали 0,87 кг корму в розрахунку на одну голову, що на 0,12 кг більше, ніж їх аналоги, які утримувались в станках з бетонною перфорованою підлогою, i, як наслідок, більш інтенсивно росли. Більш комфортні умови утримання поросят контрольної групи в екстремальний зимовий період вплинули на їх апетит і сприяли вищому на $86 \Gamma(\mathrm{p} \leq 0,001)$ середньодобовому приросту, який склав у них 467 г. Як наслідок, у тварин цієї групи абсолютний приріст живої маси склав $23,84$ кг і був вищим на 4,4 кг ( $\leq \leq 0,001)$, або на $18,5 \%$. Вищим у них на 10,2 \% виявився і відносний приріст. У результаті цього, по закінченню періоду дорощування, підсвинки контрольної групи мали індивідуальну живу масу 31,33 кг, тоді як їхні аналоги з дослідної групи досягли живої маси у цей період 26,98 кг, що на 4,35 кг, або $13,1 \%(\mathrm{p} \leq 0,001)$ менше.
Підвищений апетит завдяки кращим умовам утримання, який викликав підвищену інтенсивність росту, сприяв і поліпшенню на 0,11 кг $(0,13$ корм. од.), або на 5,0 \% конверсії корму, яка склала у поросят, котрі дорощувались у станках з полімерною підлогою, 1,87 кг (2,16 корм. од.)

У жорстких умовах зимового періоду майже третині поросят дослідної групи було надано ветеринарну допомогу, тоді як поросятам, які утримувались на полімерній підлозі, така допомога знадобилась в 12,3\%.

Відповідно зросла на 5,9\% частка вибуття тварин, які утримувались у станках з бетонною перфорованою підлогою. Зросла також на 2,1\% частка загиблих тварин.

Таким чином, у зимовий період тип підлоги в станку суттєво вплинув на інтенсивність росту поросят, конверсію корму та частку тварин, які вибули і загинули.

3 настанням більш сприятливих умов зовнішнього середовища, навесні спостерігалося зменшення різниці за продуктивністю тварин, які утримувались у станках 3 різним типом підлоги. Як і в взимку, суттєвої різниці між масою тварин при постановці на дорощування контрольної та дослідної груп не спостерігалось. Тоді як при переведенні на відгодівлю жива маса тварин дослідної групи склала 28,56 кг, що на 2,43 кг, або 7,8 \% $(\mathrm{p} \leq 0,01)$ менше їхніх аналогів 3 контрольної групи. Цей факт спричинений вищою інтенсивністю росту поросят контрольної групи, які щодоби приростали по 450 г, що на 49 г, або на 10,9 \% більше, ніж у тварин, які утримувались на бетонній підлозі i, як наслідок, вони мали на 2,49 кг (10,9\%) вищий абсолютний приріст і на 6,1 \% відносний.

Щодоби поросята, які утримувались в станках 3 бетонною полімерною підлогою, споживали 0,72 кг корму, що на 0,06 кг (7,7 \%) менше і мали на 0,06 кг, або 0,07 корм. од. (3,5\%) гіршу конверсію корм, яка склала у них 1,79 кг, або 2,09 корм. од.

Покращення умов зовнішнього середовища зменшило частку тварин, які потребували ветеринарної допомоги, до 16,2 \% в дослідній групі та 8,3\% - у контрольній. Також навесні зменшилась кількість тварин, які вибули, у дослідній групі до 7,9\%, тоді як у контрольній вона підвищилась до 3,8\%. Частка загиблих тварин у дослідній групі зменшилась порівняно із зимовим періодом та склала 3,5 \%. Водночас у контрольній групі вона підвищилась у порівнянні із зимовим періодом та склала 2,3\%.

Таким чином і у весняний період, як і в інші пори року, продуктивність тварин суттєво залежала від типу підлоги у станку. 


\section{СІЛЬСЬКЕ ГОСПОДАРСТВО. ТВАРИННИЦТВО}

Тварини, які утримувались у станках із полімерною перфорованою підлогою, споживали щодоби більше корму, більш інтенсивно росли, краще оплачували корм приростами та мали суттєво вищу живу масу при переведенні на відгодівлю. Стан здоров'я та збереженість поросят також був кращим у станках із полімерною підлогою у порівнянні з бетонною.

Результати, отримані влітку свідчать, що тип підлоги у станках для утримання поросят на дорощуванні також мав суттєвий вплив на інтенсивність їхнього росту. Так, при завершенні дорощування жива маса поросят дослідної групи склала 28,5 кг, тоді як різниця за нею вірогідно $(\mathrm{p} \leq 0,01)$ склала 2,69 кг, або 8,4\% на користь тварин контрольної групи, які утримувались у станках із полімерною підлогою. Вищим у них виявився i абсолютний приріст, який за період дорощування склав 23,20 кг, тоді як у тварин дослідної групи, які утримувались на бетонній перфорованій підлозі, тільки 20,65 кг, що на 2,55 кг, або 11,0\% менше $(\mathrm{p} \leq 0,01)$.

Щодоби поросята контрольної групи приростали на 455 г, тоді як їхні аналоги дослідної групи мали середньодобовий приріст на 26 г $(\mathrm{p} \leq 0,05)$, або 5,7 \% нижчий.

Відносний приріст поросят дослідної групи виявився на 4,8\% нижчим порівняно 3 їх аналогами, які утримувались у станках на полімерній підлозі.

Умови утримання поросят вплинули на їхній апетит i, відповідно, на кількість спожитого корму. Так, поросята, які утримувались на більш комфортній полімерній підлозі, щодоби споживали 0,85 кг комбікорму, тоді як їх аналоги 3 дослідної групи, в станках для утримання яких використовували бетонну щілинну підлогу, тільки 0,78 кг, що менше на 9,0\%.

Більш комфортні умови утримання в станках 3 полімерною підлогою, за рахунок вищої інтенсивності росту поросят, сприяли зменшенню витрат кормів на одиницю приросту. Так, на 1 кг приросту тварини контрольної групи витрачали 1,87 кг комбікорму, що склало 2,19 корм. од., тоді як їх ровесники 3 дослідної - 1,93 кг, або 2,26 корм. од.

Тип підлоги у станках для утримання поросят вплинув і на стан їхньої захворюваності та на відсоток їх вибуття і загибелі, з якого витікає, що позапланової ветеринарної допомого було надано 6,4 \% тваринам контрольної групи, які утримувались на полімерній підлозі, тоді як 17,3 \% їх аналогів 3 дослідної, які утримувались на бетонній підлозі, потребували позапланового ветеринарного втручання.
Вищою у дослідній групі виявилась і частка втрат поголів'я за час дорощування, яка склала 3,46 \% проти 3,00\% у контрольній.

Відсоток загибелі тварин виявився також вищим серед поросят дослідної групи - 2,05\% проти $1,13 \%$ у контрольній.

Восени за 51 добу дорощування тварини контрольної групи приросли до 24,08 кг, тоді як їх аналоги 3 дослідної групи мали вірогідно $(\mathrm{p} \leq 0,001)$ абсолютний приріст за цей період на 3,73 кг, або 15,5 \% менше. Це спричинило і різну живу масу тварин при завершенні терміну дорощування. Так, поросята контрольної групи, які утримувались на полімерній решітчастій підлозі, мали середню житву масу при завершенні періоду дорощування 32,12 кг, що вірогідно $(\mathrm{p} \leq 0,001)$ на 3,79 кг $(13,4 \%)$ вище у порівнянні 3 їхніми ровесниками, які утримувались в цей час на бетонній перфорованій підлозі.

Тварини, які утримувались в станках із полімерною підлогою, виявили вищу інтенсивність росту. Щодоби вони приростали в середньому на 472 г, в той час як їх аналоги $з$ дослідної групи мали середньодобові прирости за цей же період вірогідно на 73 г $(15,4 \%)$ нижчі $(\mathrm{p} \leq 0,001)$. Відносний приріст також виявився вищим на 7,8 \% порівняно $з$ тваринами дослідної групи.

Поросята контрольної групи щодоби споживали на 0,1 кг (12,0\%) більше корму, що посприяло вищій енергії їхнього росту i, як результат, призвело до кращої на 0,07 кг, або 0,08 корм. од. (4,0 \%) конверсії корму.

Як і в літній період, восени більшій кількості поросят дослідної групи знадобилася ветеринарна допомога. Так, 21,2 \% поросят дослідної групи потребували ветеринарної допомоги, тоді як їхнім аналогам, які утримувались на полімерній підлозі, така допомога надавалася у 8,3 \% випадках. Умови утримання вплинули на кількість тварин, які вибули. Так, за період дорощування iз контрольної групи вибуло 2,8 \% поросят, тоді як із дослідної - 5,1\%. Меншим у тварин контрольної групи був і відсоток загиблих поросят, який склав 1,9\%, тоді як у дослідній він склав $2,8 \%$.

Таким чином, тип підлоги у станку при утриманні поросят на дорощуванні в осінній період мав суттєвий вплив на споживання корму i, як наслідок, на інтенсивність росту поросят i, відповідно, на абсолютний приріст та кінцеву живу масу поросят при дорощуванні.

Висновок. Встановлено залежність продуктивності поросят на дорощуванні від типу перфорованої підлоги у станку вподовж усіх пір року. 


\section{СІЛЬСЬКЕ ГОСПОДАРСТВО. ТВАРИННИЦТВО}

Взимку поросята, які дорощувались із заміною в станку полімерної перфорованої підлоги на бетонну, щодоби споживали, у розрахунку на одну голову, на 13,8 \% менше корму, мали на $18,4 \%$ нижчі середньодобові прирости, на $18,5 \%$ - абсолютні та на 10,2 \% - відносні, в результаті чого при його закінченні мали меншу на $13,1 \%$ живу масу. У них також на 5,0 \% була гіршою конверсія корму та на 5,9\% - збереженість поросят, ніж у їх аналогів, які утримувались у станках із полімерною перфорованою підлогою.

Навесні поросята, які дорощувались на бетонній перфорованій підлозі, при його завершенні мали меншу на 7,8\% масу, у них встановлено нижчі на 10,9\% середньодобові прирости, на $10,9 \%$ - абсолютні та на 6,1 \% - відносні. Вони споживали щодоби менше на 7,7 \% корму, мали на $3,5 \%$ гіршу його конверсію порівняно 3 їх

\section{БІБЛІОГРАФІЯ}

1. Бугаєвський В. М., Остапенко О. М., Данильчук M. I. Вплив середовища та технології утримання на продуктивність свиней // Наукові праці МДГУ. - 2010. - Вип. 119. - Т. 132. - С. 59-61.

2. Демчук М. В., Решетник А. О., Ковальчук O. М., Головань А. О. Інтенсивна технологія виробництва свинини 3 врахуванням добробуту свиней // Збірник наукових праць «Проблеми зооінженерії та ветеринарної медицини Харківської державної зооветеринарної академії. 2010. №22 (2). - С. 390-397.

3. Еріксон Д. Американська технологія утримання свиней (від відлучення до забою) // Прибуткове свинарство. - 2015. - №3 (27). - С. 64-67.

4. Коваль О. А., Калиниченко Г. І. Ефективність вирощування ремонтного молодняку свиней на решітчастій підлозі // Збірник наукових праць Вінницького національного аграрного університету. - Серія : Сільськогосподарські науки. 2012. - Вип. 5 (67). - С. 124-125.

5. Лихач В. Технологічні особливості вирощування поросят // Тваринництво України. - 2015. - №6. - C. 11-13.

6. Повод М. Г., Шиетний М. Б. Сезонна проду-

\section{ANNOTATION}

Povod M. G., Shpetnyi M. B. Seasonal dynamics of productivity of piglets at growing them in pens with different type of floor.

The seasonal dynamics of piglets' productivity was studied at growing them in the pens with polymeric and concrete perforated floors. The depend- ровесниками, які дорощувались на полімерній перфорованій підлозі.

Влітку різниця між поросятами, які утримувались на бетонній i полімерній перфорованих підлогах, склала за середньодобовими приростами 5,7\%, абсолютними приростами - $11,0 \%$, відносними приростами - 4,8\%, конверсією корму - 3,2 \%, збереженістю - 3,0 \% на користь тварин, які утримувались на полімерній підлозі. Вони щодоби споживали на 9,0 \% менше корму і на кінець періоду дорощування мали на 8,4\% меншу живу масу.

Восени тварини, які дорощувались на бетонній підлозі, щодоби споживали на 12,0 \% менше корму, мали нижчі на $15,4 \%$ середньодобові прирости, на 15,5\% - абсолютні та на 7,8 \% відносні, на 4,0 \% гіршу конверсію корму та на 4,0 \% - збереженість поросят, і на кінець періоду дорощування мали меншу на 9,1 \% живу масу.

ктивність поросят на дорощуванні у станках за різного розміру груп та типу підлоги // Науковотехнічний бюлетень IT НААН. - 2016. - №116. C. 126-134.

7. Решетник А. О., Смоляк В. В., ЛайтерМоскалюк C. В. Стан добробуту свиней у промисловому свинарстві // Науковий вісник ЛНУВМБТ ім. С. 3. Гжицького. - 2016. - Т. 18. №4 (72). - C. 66-71.

8. Садомов Н. А. Энергия роста поросят на доращивании в зависимости от способа содержания : материалы XVIII Международной научнопрактической конференции, посвященной 85летию зооинженерного факультета и 175-летию УО «Актуальные проблемы интенсивного развития животноводства». Белорусская государственная сельскохозяйственная академия (г. Горки, 28-29 мая 2015 г.). - С. 163-166.

9. Чёрныци Н. В., Онокиенко Н. И., Момот Л. Н. Влияние полов на здоровье свиней // Пути интенсификации отрасли свиноводства в странах СНГ : тез. докл. XIII междунар. науч.-практ. конф. - Жодино, 2006. - С. 162-163.

ence of piglets' productivity on growing from the type of perforated floor in the pen was determined all the time of the year.

In winter, piglets that were growing with replacement in the pen polymer perforated floors on concrete, daily consumed per each by $13.8 \%$ less 


\section{СІЛЬСЬКЕ ГОСПОДАРСТВО. ТВАРИННИЦТВО}

feed, had $18.4 \%$ lower than the daily average, $18.5 \%$ absolute and $10.2 \%$ relative increase, resulting in a decrease by $13.1 \%$ of live weight at its completion. They also had a worse feed conversion by $5.0 \%$ and $5.9 \%$ piglet survival than their counterparts who were kept in pens with a polymeric perforated floor.

Spring piglets that growing on a perforated concrete floor were on $7.8 \%$ lower in weight, they found $10.9 \%$ lower average daily, $10.9 \%$ absolute and relative $6.1 \%$ increase in body weight. They consumed less than $7.7 \%$ of food each day, had a $3.5 \%$ worse conversion than their peers, who were grown on a polymeric perforated floor.

In summer the difference between piglets, which were kept on the concrete and polymer perforated floors, was for the average daily gains of $5.7 \%$, absolute growth $-11.0 \%$, relative growth $-4.8 \%$, feed conversion $-3.2 \%$, preservation $-3.0 \%$ in favor of animals, which were kept on the polymer floor. They consumed $9.0 \%$ less feed daily and had $8.4 \%$ less weight at the end of growing period.

In autumn animals that were grown on the concrete floor daily consumed by $12.0 \%$ less feed, had $15.4 \%$ lower average daily, $15.5 \%$ absolute and $7.8 \%$ relative gains, $4.0 \%$ lower feed conversion and by $4.0 \%$ lower piglets survival and at the end of growing period had a smaller by $9.1 \%$ live weight.

Key words: piglets, type of floor, average daily gain, feed intake, feed conversion, preservation. 